\title{
A comparison of predictive phosphorus load- concentration models for lakes
}

by Andreas C Bryhn and Lars Håkanson, 2007

Originally published in Ecosystems, 10: 1084-1099

Copyright holders: Springer Science and Business Media, Inc. The original

publication is available at http://www.springerlink.com/content/j3v8130677hm2032/

Published according to the copyright holders' rules for self-archiving as stated on May 19, 2008 at http://www.springer.com/life+sci/ecology/journal/10021?detailsPage=copyrightInformation 


\title{
A Comparison of Predictive Phosphorus Load-Concentration Models for Lakes
}

\author{
Andreas C. Bryhn, ${ }^{*}$ and Lars Håkanson \\ Department of Earth Sciences, Uppsala University, Villav. 16, Uppsala, 752 36, Sweden
}

\begin{abstract}
Lake models that predict phosphorus (P) concentrations from P-loading have provided important knowledge enabling successful restoration of many eutrophic lakes during the last decades. However, the first-generation (static) models were rather imprecise and some nutrient abatement programs have therefore produced disappointingly modest results. This study compares 12 first-generation models with three newer ones. These newer models are dynamic (time-dependent), and general in the sense that they work without any further calibration for lakes from a wide limnological domain. However, static models are more accessible to nonspecialists. Predictions of $\mathrm{P}$ concentrations were compared with empirical long-term data from a
\end{abstract}

\section{INTRODUCTION}

Restoration of anthropogenically eutrophic lakes in many parts of the world has been a true ecological success story. Signs of lake eutrophication have been reported since the late 19th century (Hasler 1947) although the scientific foundation for a large number of successful restoration programs was provided much later, in the 1960s and 1970s. Vollenweider $(1968,1976)$ correlated nutrient concentrations in surface waters to nutrient loads and provided algorithms for calculating nutrient retention in lakes. Several Canadian whole-lake

Received 27 November 2006; accepted 29 June 2007; published online 22 August 2007.

*Corresponding author; e-mail: Andreas.Bryhn@geo.uu.se multi-lake survey, as well as to data from transient conditions in six lakes. Dynamic models were found to predict $\mathrm{P}$ concentrations with much higher certainty than static models. One general dynamic model, LakeMab, works for both deep and shallow lakes and can, in contrast to static models, predict $\mathrm{P}$ fluxes and particulate and dissolved $\mathrm{P}$, both in surface waters and deep waters. PCLake, another general dynamic model, has advantages that resemble those of LakeMab, except that it needs three or four more input variables and is only valid for shallow lakes.

Key words: eutrophication; phosphorus; lakes; fluxes; predictive power; modelling. experiments showed that long-term chlorophyll-a (Chl) concentrations were affected by variations in total phosphorus (TP) loads but not by total nitrogen loads, because nitrogen fixation counteracted long-term nitrogen deficits (Schindler 1977). Consequently, nutrient abatement in lakes has focused on TP, which is strongly correlated with Chl (Dillon and Rigler 1974) as well as with many other management-related variables such as fish yield and blue-green algae (Peters 1986). Dissolved inorganic nutrients are, on the other hand, poorly correlated with $\mathrm{Chl}$ and other trophic status indicators (Pienitz and others 1997). Even though algae may not directly utilize TP but primarily dissolved inorganic nutrients, the latter have rapid turnover times because they are quickly regenerated and their supply is therefore often not reflected by their 
concentrations (Dodds 2003). Reductions in TP loads to lakes have generally resulted in a new equilibrium of lower trophic status after 10 15 years (Jeppesen and others 2005), but many models for predicting future TP and Chl concentrations are rather imprecise and results from some abatement programs have therefore been disappointingly modest (Sas 1989). During recent decades there has been substantial interest in developing and improving models that predict algal biomass and other indicators of eutrophication, and eutrophication effects on, for example, oxygen concentrations in bottom waters or foodweb interactions (Håkanson and Boulion 2002; Zhang and others 2004; Arhonditsis and Brett 2005; Janse 2005). The scope of the present work is limited to the primary cause of eutrophication and its reversal, that is, to variations in phosphorus loads and concentrations.

All predictive phosphorus $(\mathrm{P})$ models are more or less empirical and more or less mechanistic (Aldenberg and others 1995) and it is therefore more useful to divide these models into static and dynamic categories. Static models use a steady-state assumption; that is, that the lake has received a rather constant nutrient input for a long time. These models are used to calculate the TP concentration in lake water $\left(C_{\text {lake }}\right)$ from a set of lake-specific parameters. Dynamic models consist of ordinary or partial differential equations and can simulate changes over time in, for example, nutrient load. Some of them require many more input parameters than static models. Many of those driving variables may be very uncertain and the knowledge of such variations and uncertainties is often very poor (Jensen and others 2006). Therefore, a great challenge in dynamical modeling is to avoid such uncertain parameters.

Two important and critical steps in ecological model development are model calibration against empirical data and validation, preferably against "independent" data (that is, data that were not used during calibration; Jackson and others 2000). To convey any scientific information, models need to be refutable; that is, it must be possible to falsify them with evidence of the opposite (Popper 1972). If a model needs to be calibrated for each situation, careful calibration is likely to guarantee a true solution every time, making refutation impossible (Peters 1991). To circumvent this dilemma, a lake-specific model may be validated against data from a period when the nutrient input was different from the period for which the model was calibrated [see, for example, Schladow and Hamilton (1997), Zhang and others 2004and
Arhonditsis and Brett (2005); and references therein]. However, a lake-specific model may nevertheless deliver the right predictions for the wrong reasons during validations, because the error from one faulty parameter may have been corrected during calibration by tuning other parameters to incorrect values (Oreskes and others 1994). This risk can be decreased if the model is general; that is, calibrated and validated for a large number of lakes and thereafter used without further tuning (Aldenberg and others 1995). Furthermore, a general model has a wider range of applicability, increasing chances of correct predictions if the studied lake will be subject to unprecedented environmental changes in the future. General models can be refuted if enough empirical observations systematically fall outside model predictions. Static P models are often valid for several lakes (Meeuwig and Peters 1996), and there are also a few general dynamic P models available. We have found three in the literature; PCLake (Aldenberg and others 1995), LakeMab and its ancestors (Håkanson and Peters 1995; Håkanson and Boulion 2002; Malmaeus and Håkanson 2004), and a nameless model by Jensen and others (2006); hereafter referred to as the JPJS model where the acronym denotes the initials of the authors' last names.

Environmental protection agencies (EPAs) in many countries have access to well-tested general models for estimating $\mathrm{P}$ load from watersheds to lakes. However, watershed models do not take the internal loading from lake sediments to the water column into account (de Madariaga and others 2006). Lake-specific models are also being used by many EPAs to estimate the internal load for wellstudied lakes, although such models are associated with the shortcomings mentioned above. As an alternative, models that can predict the internal loading in a generic manner (such as the models presented in this work) could serve as a powerful complement to presently used management models and may thus improve the certainty in predicted outcome of lake restoration programs. Furthermore, generic models are particularly useful for creating general policy guidelines that also apply to lakes which have only been studied briefly.

This study aims at studying and comparing: (1) the predictive power of various generic phosphorus load-concentration models, (2) model input requirements, (3) what kind of predictions the models can deliver, (4) how well internal phosphorus fluxes are described, and (5) how accessible the models are to non-specialists. 
Table 1. Twelve Static Models for Calculating $C_{\text {lake, }}$ the TP Concentration (in $\mu \mathrm{g} \mathrm{L}^{-1}$ ) in Lakes

\begin{tabular}{lll}
\hline Model name & Equation & References \\
\hline K\&D & $C_{\text {in }}\left(1-0.426 \cdot \mathrm{e}^{\left(-0.271 D_{m} / T\right)}-0.574 \cdot \mathrm{e}^{\left(-0.00949 D_{m} / T\right)}\right)$ & Kirchner and Dillon (1975) \\
LEM 1 & $C_{\text {in }}(1-0.482+0.112 \operatorname{In}(1 / T))$ & Larsen and Mercier $(1976)$ \\
LEM 2 & $C_{\text {in }}\left(1-11.73 /\left(11.73+D_{m} / T\right)\right)$ & Larsen and Mercier $(1976)$ \\
LEM 3 & $C_{\text {in }}\left(1-0.854+0.142 \operatorname{In}\left(\mathrm{D}_{\mathrm{m}} / T\right)\right)$ & Larsen and Mercier (1976) \\
Nürnberg & $C_{\text {in }}\left(1-15 /\left(18+D_{m} / T\right)\right)$ & Nürnberg (1984) \\
OECD & $1.55\left(C_{i n} /\left(1+T^{0.5}\right)\right)^{0.82}$ & Håkanson and Peters (1995) \\
Ostrofsky 1 & $C_{\text {in }}\left(1-24 /\left(30+D_{m} / T\right)\right)$ & Ostrofsky (1978) \\
Ostrofsky 2 & $C_{\text {in }}\left(1-0.6852 \cdot \mathrm{e}^{\left(-0.0147 D_{m} / T\right)}\right)$ & Ostrofsky (1978) \\
Ostrofsky 3 & $C_{\text {in }}\left(1-\left(0.886-0.145 \operatorname{In}\left(D_{m} / T\right)\right)\right)$ & Ostrofsky (1978) \\
Ostrofsky 4 & $C_{\text {in }}\left(1-0.201 \cdot \mathrm{e}^{\left(-0.0425 D_{m} / T\right)}-0.574 \cdot \mathrm{e}^{\left(-0.00949 D_{m} / T\right)}\right)$ & Ostrofsky $(1978)$ \\
Vollenwe ider & $C_{\text {in }} /\left(1+T^{0.5}\right)$ & Håkanson and Peters $(1995)$ \\
Walker & $C_{\text {in }} /\left(1+0.824 \cdot T^{454}\right)$ & Reckhow $(1988)$
\end{tabular}

The TP concentration in the inflow $\left(C_{i n}\right)$ is given in $\mu g L^{-1}$, the mean depth $\left(D_{m}\right)$ in meters, and the retention time $(T)$ in years

\section{Model Descriptions}

\section{Static Phosphorus Models}

Most static P models are fairly similarly designed [for reviews, see Ahlgren and others (1988), Meeuwig and Peters (1996) and the references in Table 1]. They describe the lake water as a completely mixed reactor in steady-state (Figure 1) and contain one or a few basic equations that are used to calculate how much of the phosphorus load goes out with the outflowing water and how much is retained in the lake; that is, mixes, settles and buries in the sediment. Output variables are the TP concentration in lake water $\left(C_{\text {lake }}\right)$ and the TP retention $(R)$, which is often expressed as a ratio between how much TP is retained and how much TP was added to the lake. Typical input variables are the TP concentration in the inflow $\left(C_{\text {in }}\right)$, water retention time ( $T$; which expresses how long the average water molecule stays in the lake) and sometimes the lake mean depth $\left(D_{m}\right)$. These variables may be presented in several variants. For example, $C_{\text {in }}$ and $D_{m}$ are sometimes expressed as a ratio between the former and the latter, whereas $T$ is often replaced by its inverse, the retention rate or the flushing rate. The static $\mathrm{P}$ models tested and discussed in this work are listed in Table 1. Most of them were developed in the 1970s or early-1980s. $C_{\text {in }}$ is measured directly, although its spatial and temporal variability may be substantial and has to be accounted for. $D_{m}$ requires a morphometric survey of the lake, as well as recordings of the water level fluctuations if they are substantial. A morphometric survey is also necessary to get data on $T$, which is calculated as the lake volume $(V)$ divided by the water flux $(Q)$. Due to their

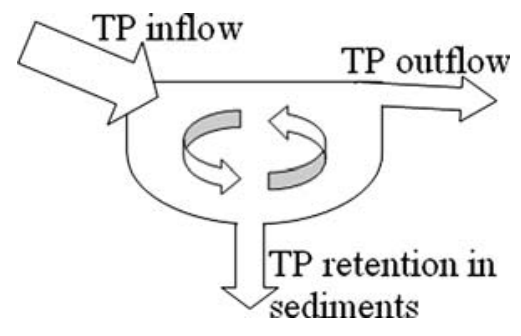

Figure 1. A conceptual description of a static model for $\mathrm{TP}$ in lakes. The TP that flows into the lake either flows out or is retained in sediments.

simplicity, static models are easy to use for nonspecialists. However, for lakes recovering from eutrophication, static models tend to underestimate the internal loading and therefore predict TP in lakes dominated by internal loading particularly poorly because recovering lakes are not in a steady state (Jensen and others 2006).

\section{The JPJS Model}

The JPJS model was developed for 16 shallow, eutrophic Danish lakes and is intended for describing the recovery process after nutrient abatement has started. It is primarily suited for modelling the seasonal TP dynamics. The construction of the JPJS model is more complex than static models but still very simple compared to most other dynamic models. The JPJS model contains two state variables, TP mass in lake water and TP mass in lake sediments, whose dynamic values are determined by their initial values and two differential equations (Figure 2). Input variables to the model are $C_{\text {in }}$ and $T$, and during model development, the initial values of TP in sediments have 


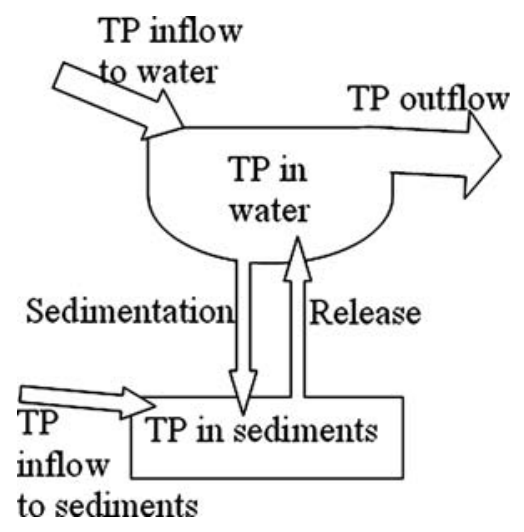

Figure 2. A structural description of the JPJS TP model.

been calibrated for each lake to suit empirical data on $C_{\text {lake }}$ (Jensen and others 2006). Thus, even though the model has been developed for several lakes, it cannot be applied for any lake in its domain without calibration. Output variables are $C_{\text {lake }}, R$, TP sedimentation and sediment TP release.

\section{PCLake}

PCLake is a general model for phosphorus, nitrogen, silica and several biotic variables in shallow lakes. It was calibrated against 43 lakes simultaneously with Bayesian statistics and then tested on data from nine lakes by Janse (2005), following a similar calibration procedure on 18 lakes by Aldenberg and others (1995). Bayesian statistics allow for a stepwise type of calibration of unknown parameters in a manner that gradually decreases model uncertainty. Furthermore, the Bayesian method includes probability distributions of parameters and uncertainty analyses for model predictions. PCLake can simulate $C_{\text {lake }}$ during both stable and transient conditions and thus estimate how shallow lakes respond to changes in nutrient loading. Because PCLake is comparative, it can rank which types of lakes are more susceptible to eutrophication than others, and it can also be an important tool for ranking the predicted success of different management options (Janse 2005).

PCLake is rather extensive, and in addition to quantifying TP it also accounts for several P fractions. Although a meta-model has been developed (Vleeshouwers and others 2004), PCLake still needs to be run by specialists. Figure 3 shows a very simplified structural scheme of the TP cycle in PCLake. There are 19 state variables for various $P$ fractions (not shown in Figure 3) that are distributed between the water and the sediment. Output variables are $C_{\text {lake }}, R$, concentrations of phosphate, phosphorus in detritus and phosphorus adsorbed

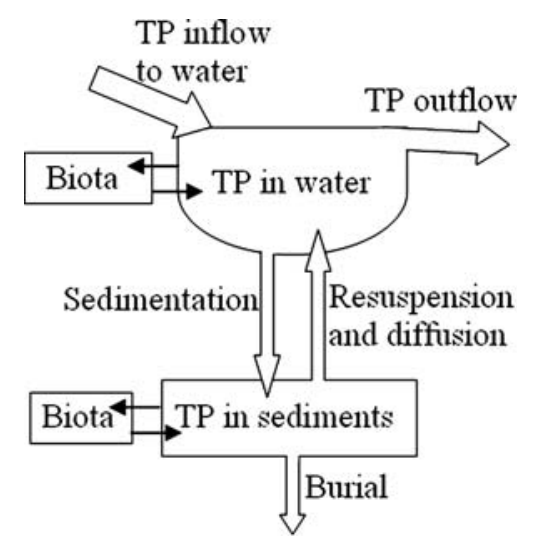

Figure 3. A simplified structural description of the TP sub-model in PCLake. PCLake contains 19 state variables for various $P$ fractions (not shown) that are distributed between the water and the sediment.

onto inorganic matter, and several fluxes such as sedimentation, diffusion, resuspension, mineralization, sorption, and uptake and release by biota. Input variables are $D_{m}$, fetch, sediment characteristics, marsh area (if any), $T$ (or $Q$ ), $C_{\mathrm{in}}$, temperature and daylight. A morphometric survey needed to calculate $T$ can also be used to estimate the fetch. Temperature and daylight should be monitored regularly and such input variables can often be accessed relatively easily from universities and government agencies. However, sediment characteristics and marsh area require separate field investigations.

\section{LakeMab}

LakeMab is a general model that may be used without calibration for all types of substances in lakes and it was originally developed for radiocesium and radiostrontium. As a consequence of the chernobyl nuclear accident, the pulse of radionuclides that subsequently passed along European ecosystem pathways made it possible to quantify the most important transport routes of the radionuclides (Håkanson 2000). Many algorithms that quantify these routes are valid not just for radionuclides, but have also been validated for suspended particulate matter (Håkanson 2006) and phosphorus. The TP version of LakeMab has been used as a basis for a foodweb model [LakeWeb, see Håkanson and Boulion (2002)] and its purposes therefore coincide with those of PCLake, with the difference that the latter is designed for shallow lakes whereas the former is designed for both deep and shallow lakes. LakeMab accounts for dissolved and particulate P pools, whereas PCLake models account for even more $\mathrm{P}$ fractions. LakeMab needs 


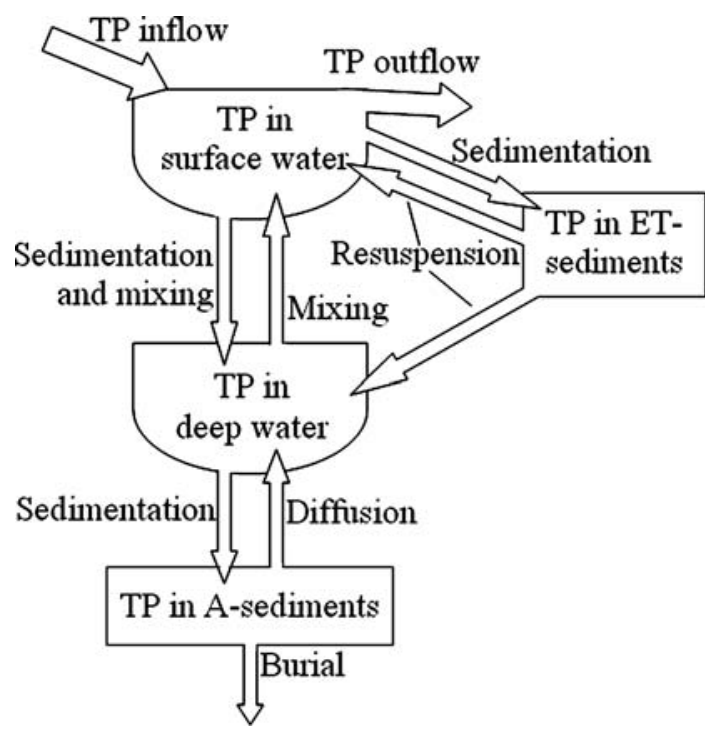

Figure 4. A structural description of LakeMab for TP. LakeMab differs between erosion and transport (ET-) and accumulation (A-)sediments.

to be run by specialists and is more complex than the JPJS model but less complex than PCLake and has four state variables; TP in surface water, TP in bottom water, TP in erosion and transport (ET)sediments and TP in accumulation (A-)sediments (Figure 4). It is described in detail in Håkanson and Boulion (2002).

\section{A Static Water Flux Model}

$Q$ is one driving variable that can be measured directly in tributaries. This is evidently a procedure that requires a considerable amount of resources. An alternative method to estimate $Q$ on a monthly or yearly basis that is included in LakeMab is a static model developed by Abrahamsson and Håkanson (1998), using an extensive data set from more than 200 European rivers. The Q model only requires driving variables available from standard maps. It is intended to yield predictions of $Q$, which can be accepted in ecosystem models where the focus is on, for example, the predictive power for the concentration of pollutants in water, sediments and biota.

Figure 5 exemplifies a basic component of this Q model, the relationship between mean annual water discharge ( $Q$ in $\left.\mathrm{m}^{3} / \mathrm{s}\right)$ and the area of the catchment (ADA; in $\mathrm{km}^{2}$ ). From this regression, mean monthly $Q$ is calculated from:

$$
Q_{\text {month }}=\mathrm{ADA}\left(\text { Prec/650) } Y_{Q}\right.
$$

where Prec is the mean annual precipitation, the ratio (Prec/650) is a dimensionless moderator based

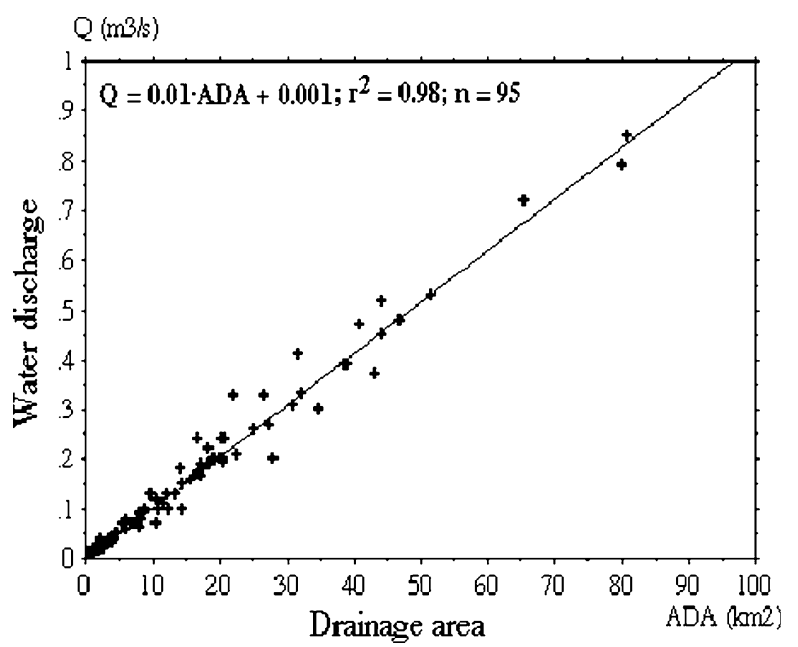

Figure 5. The relationship between the area of the drainage area (ADA in $\mathrm{km}^{2}$ ) and the mean annual water discharge $(Q)$ using data from 95 catchments areas from boreal landscapes [data from Håkanson and Peters (1995)].

on the regression in Figure 5, which is related to lakes with an average mean annual precipitation of $650 \mathrm{~mm} \mathrm{y}^{-1}$. $Y_{Q}$ in Eq. 1 is a dimensionless moderator that accounts for how monthly water discharge values relate to annual values, and this relationship depends on the latitude and altitude.

Output variables from LakeMab are $C_{\text {lake }} R$, concentrations of dissolved and particulate $P$ in surface waters and deep waters, sedimentation, diffusion, burial, resuspension, uptake and release by biota [if connected to LakeWeb; see Håkanson and Boulion (2002)], mixing between surface waters and deep waters, and the depth of the thermocline. With Eq. 1 in use, input variables are $C_{\text {in, }}$, $\mathrm{ADA}$, latitude, altitude, Prec, lake area, maximum depth and mean depth. ADA can be calculated with high precision using a digital elevation map and geographical information system (GIS) tools. Latitude, altitude and Prec are easy to obtain from standard maps and surveys.

\section{Predicting Long-term Median Values}

The relative quality of a model compared to others is decided by is its predictive power (Aldenberg and others 1995). The predictive power can be estimated by the $r^{2}$-value generated by regressing modelled data against empirical data. The relationship between the predictive power and the $r^{2}$ value has been demonstrated by Prairie (1996) and is referred to as Prairie's staircase. The distance between the uncertainty bands is measured by the number of "steps" in a "staircase" drawn between 
the bands. The number of steps is low and fairly equal for $r^{2}$ values between 0 and 0.75 and then increases rather dramatically for each percentage point increase in $r^{2}$, which underlines the need to search for high $r^{2}$ values. Another simple method for measuring predictive power is to calculate the relative error of the various predictions, according to Eq. 2:

$$
\text { Relative error }=\frac{(\text { predicted value }- \text { empirical value })}{\text { empirical value }}
$$

For an ideal model, both the median (and mean) value and the standard deviation of the predictions' relative errors should be zero. A positive median value means that the predictions are exaggerated, whereas a negative value indicates that predictions are underestimated.

To evaluate the quality difference between the models, we tested how well LakeMab and the static models in Table 1 predicted $C_{\text {lake }}$ compared to empirical data. The data set used in the test covered 41 lakes from the northern hemisphere. Tables 2 and 3 give a compilation of data on latitude (from 28.6 to $68.5^{\circ} \mathrm{N}$ ), lake area (from 0.014 to $3,555 \mathrm{~km}^{2}$ ), maximum depth (from 4.5 to $449 \mathrm{~m}$ ), mean depth (from 1.2 to $177 \mathrm{~m}$ ), annual precipitation (from 600 to $1900 \mathrm{~mm} \mathrm{y}^{-1}$ ), drainage area (from 0.11 to $44,200 \mathrm{~km}^{2}$ ), altitude (11-850 masl), empirical TP in the water (from 4 to $1,100 \mu \mathrm{g} / \mathrm{L}$ ). These lakes cover a very wide domain in terms of size and form as well as geographical distribution and trophic status. The lakes were selected based on the following two criteria: (1) they had all been thoroughly studied and (2) there were either laketypical (median) data available on TP concentrations in the water (as expressed in Table 3), or long time series with data covering a large part of the history that preceded the eutrophication period. For lakes with long time series available, median TP-values were calculated (Table 3 ) and used in the comparisons. The literature references given in Table 4 provide more information on the lakes and the reliability and variability of the data.

The static models were run to predict $C_{\text {lake, }}$ whereas LakeMab predicted $C_{\text {lake }}$ or TP concentrations in surface waters $\left(C_{\mathrm{SW}}\right)$, depending on which empirical data were available. The inability to model $C_{\mathrm{SW}}$ is a clear disadvantage of the static models because there may be major differences between $C_{\text {lake }}$ and $C_{\mathrm{SW}}$ in many lakes. However, predictions did not improve when lakes with no data available on $C_{\text {lake }}$ were omitted. Figure 6 shows the relative error for predictions of $C_{\text {lake }}$ by
LakeMab and the static model Ostrofsky 2 (Table 1). Both models generated mean relative errors close to zero, but errors from Ostrofsky 2 showed greater variability than errors from LakeMab. Table 5 lists median relative errors from all investigated models, and it is evident that LakeMab outperformed the rest. Many models produced small mean relative errors, but LakeMab generated a much smaller standard deviation in errors than the others (0.25 compared to 0.38 or more). Table 5 also displays the difference in $r^{2}$-values (using log-transformed values to achieve normal distribution) between the various models. In terms of $r^{2}$-values, LakeMab also yielded substantially better predictions $\left(r^{2}=0.96\right.$ against empirical data) than the other models $\left(r^{2} \leq 0.86\right)$.

The relative error from the static models was significantly correlated with many of the variables listed in Tables 2 and 3, whereas the error from LakeMab was independent from those variables. Forward stepwise regression was used to single out the strongest error determinant, followed by other determinants that added any degree of explanation to the correlation. Table 5 shows that many error terms were positively correlated with the relative depth $\left[D_{\text {rel, }}\right.$ a ratio based on $D_{m}$ and area; see Wetzel (2001)], whereas others were negatively correlated with area and/or $C_{\text {lake, indicating that }}$ predictions from static models were often too low for oligotrophic, shallow and small lakes and too high for hypertrophic, deep and large lakes. Table 5 also lists the absolute value of the relative error, and shows that predictions from LakeMab typically deviated by $17 \%$ from empirical data, whereas predictions from static models were usually more than $30 \%$ higher or lower than empirical data. The absolute value of the relative error from most models (Table 5) was not correlated with any of the variables listed in Tables 2 or 3, which means that predictions were equally uncertain for all types of lakes regardless of $C_{\text {lake }}, Q$, morphometry, altitude, latitude, water retention time and precipitation. However, four static models generated relatively large errors for lakes with low $Q$ values (Table 5).

\section{Phosphorus Fluxes and Concentrations During Transient Conditions}

Another clear advantage of dynamic phosphorus models over static ones is that the former can be used to calculate phosphorus fluxes, and rank them according to their relative importance. Such a comparison between fluxes is very useful when different remedial strategies are considered. If a 
Table 2. A Multi-Lake Survey of 41 Studied Lakes

\begin{tabular}{|c|c|c|c|c|c|c|c|c|}
\hline Lake name & $\begin{array}{l}\text { Latitude } \\
\left({ }^{\circ} \mathrm{N}\right)\end{array}$ & $\begin{array}{l}D_{\max } \\
(\mathrm{m})\end{array}$ & $\begin{array}{l}D_{m} \\
(m)\end{array}$ & $\begin{array}{l}\text { Area } \\
\left(\mathrm{km}^{2}\right)\end{array}$ & $\begin{array}{l}\text { Precipitation } \\
\left(\mathrm{mm} \mathrm{y}^{-1}\right)\end{array}$ & $\begin{array}{l}\text { Drainage } \\
\text { area }\left(\mathrm{km}^{2}\right)\end{array}$ & $\begin{array}{l}\text { Altitude } \\
\text { (masl) }\end{array}$ & $\begin{array}{l}\text { References }{ }^{1} \\
\text { (Table } 4 \text { ) }\end{array}$ \\
\hline Washington & 47.6 & 65.2 & 32.9 & 87.6 & 890 & 1,500 & 20 & $\mathrm{a}$ \\
\hline Blue chalk & 45.2 & 23 & 8.5 & 0.52 & 1,034 & 1.06 & 320 & $\mathrm{~b}$ \\
\hline Chub & 45.2 & 27 & 8.9 & 0.34 & 1,034 & 2.72 & 320 & $\mathrm{~b}$ \\
\hline Crosson & 45.1 & 25 & 9.2 & 0.57 & 1,034 & 5.22 & 320 & $\mathrm{~b}$ \\
\hline Dickie & 45.2 & 12 & 5 & 0.94 & 1,034 & 4.06 & 320 & $\mathrm{~b}$ \\
\hline Harp & 45.4 & 37.5 & 13.3 & 0.71 & 1,034 & 4.71 & 320 & $\mathrm{~b}$ \\
\hline Plastic & 45.2 & 16.3 & 7.9 & 0.32 & 1,034 & 0.96 & 320 & $\mathrm{~b}$ \\
\hline Red chalk & 45.2 & 38 & 14.2 & 0.57 & 1,034 & 5.32 & 320 & b, c \\
\hline Mendota & 43.0 & 23 & 12.3 & 39.4 & 768 & 604 & 850 & d \\
\hline Peipsi & 58.5 & 15.3 & 7.1 & 3,555 & 600 & 44,200 & 29.5 & $\mathrm{e}$ \\
\hline Mjøsa & 60.7 & 449 & 153 & 365 & 740 & 17,369 & 122 & $\mathrm{f}$ \\
\hline Mirror & 43.9 & 11 & 5.8 & 0.15 & 1,311 & 1.03 & 213 & $\mathrm{~g}$ \\
\hline Vättern & 58.3 & 128 & 39.8 & 1,856 & 600 & 4,500 & 88 & $\mathrm{~h}$ \\
\hline S Bergundasjön & 57.0 & 5.4 & 2.4 & 4.3 & 750 & 45.1 & 160 & $\mathrm{j}$ \\
\hline Wahnbachtalsperre & 50.8 & 42 & 16 & 1.3 & 811 & 54 & 130 & $\mathrm{k}$ \\
\hline Fuschlsee & 47.8 & 67 & 37.7 & 2.66 & 1,500 & 26.8 & 663 & 1 \\
\hline Bryrup Langsø & 56.0 & 9 & 5 & 0.38 & 700 & 48.2 & 40 & $\mathrm{~m}$ \\
\hline Salten Langsø & 56.1 & 12 & 4.1 & 3.05 & 700 & 165 & 40 & $\mathrm{~m}$ \\
\hline Walensee & 47.0 & 145 & 101 & 24.2 & 1,700 & 505 & 419 & $\mathrm{n}$ \\
\hline Maggiore & 45.7 & 370 & 177.4 & 213 & 1,700 & 6,400 & 194 & o \\
\hline Biwa & 35.2 & 104 & 38.3 & 680 & 1,900 & 3,170 & 85 & $\mathrm{p}$ \\
\hline Gjersjøen & 59.8 & 64 & 23 & 2.68 & 1,043 & 84.5 & 42 & $\mathrm{q}$ \\
\hline Võrtsjärv & 57.8 & 6 & 2.8 & 270 & 670 & 3,104 & 34 & $\mathrm{r}$ \\
\hline Tegernsee & 47.4 & 72.2 & 36.3 & 9.1 & 1,500 & 200.9 & 725 & s \\
\hline Schliersee & 47.4 & 40.3 & 23.9 & 2.22 & 1,500 & 24.8 & 780 & s \\
\hline Stugsjön & 68.5 & 4.5 & 1.2 & 0.017 & 1,000 & 0.11 & 600 & $\mathrm{t}$ \\
\hline Magnusjaure & 68.5 & 5.5 & 2.2 & 0.014 & 1,000 & 0.12 & 600 & $\mathrm{t}$ \\
\hline Lough Neagh & 54.4 & 24 & 8.9 & 387 & 860 & 4,465 & 15 & $\mathrm{u}$ \\
\hline Geneva & 46.4 & 309 & 172 & 503 & 900 & 7,395 & 372 & $\mathrm{v}$ \\
\hline Östra Ringsjön & 55.9 & 16 & 5 & 20.8 & 850 & 325 & 54 & $\mathrm{y}$ \\
\hline Västra Ringsjön & 55.9 & 6 & 3.4 & 15.4 & 850 & 347 & 54 & $\mathrm{y}$ \\
\hline Kolbotnvannet & 59.8 & 18.5 & 10.3 & 0.30 & 1,043 & 3.9 & 95 & $\mathrm{z}$ \\
\hline Lugano, N. basin & 46.0 & 288 & 171 & 27.5 & 1,700 & 270 & 271 & aа \\
\hline Apopka & 28.6 & 6 & 1.6 & 125 & 1,200 & 1,370 & 20 & $a b$ \\
\hline Bullaren & 60.0 & 26.2 & 10.1 & 8.3 & 850 & 199 & 100 & ac \\
\hline Långsjön & 60.0 & 6.2 & 2.1 & 0.13 & 811 & 3.2 & 100 & $\mathrm{ad}$ \\
\hline Balaton & 47.0 & 11 & 3.2 & 596 & 600 & 5,280 & 106 & ac \\
\hline Batorino & 54.5 & 5.5 & 3.0 & 6.3 & 650 & 93 & 165 & $\mathrm{ac}$ \\
\hline Miastro & 54.5 & 11.3 & 5.4 & 13.1 & 650 & 133 & 165 & ac \\
\hline Naroch & 54.5 & 24.8 & 9.0 & 79.6 & 650 & 279 & 163 & ac \\
\hline Erken & 59.3 & 20.7 & 9 & 23.7 & 660 & 141 & 11 & $\mathrm{ac}$ \\
\hline Minimum & 28.6 & 4.5 & 1.2 & 0.014 & 600 & 0.11 & 11 & \\
\hline Maximum & 68.5 & 449 & 177.4 & 3,555 & 1,900 & 44,200 & 850 & \\
\hline Mean & 52 & 60 & 28 & 208 & 990 & 2,380 & 250 & \\
\hline
\end{tabular}

contemplated remedial measure would result in a very small flux compared to TP input, diffusion and resuspension, then this measure will evidently cause limited change. Or, if a remedial measure has its greatest effect on diffusion (for example, artificial oxygenation of bottom waters) or resuspension (for example, induced colonization by bivalves or macrophytes), it is essential to be able to quantify these fluxes and to predict what the effect on $C_{\text {lake }}$ will be if these fluxes are altered. One lake that has been investigated with the model PCLoos, a predecessor of PCLake, is Lake Loosdrecht (The Neth- 
Table 3. Empirical Data on Water Discharge ( $Q$; needed to run the static models but not LakeMab), TP Concentrations Related to all kinds of TP Loading to the Lakes, Empirical TP Concentrations in the Lakes, either the Whole Lake or the Surface-water(=outflow) Compartment

\begin{tabular}{|c|c|c|c|c|}
\hline Lake name & $Q\left(10^{6} \mathrm{~m}^{3}\right)$ & TP inflow $(\mu \mathrm{g} / \mathrm{L})$ & TP lake $(\mu \mathrm{g} / \mathrm{L})$ & Whole lake or SW \\
\hline Washington & 1,118 & 52.5 & 20 & Lake \\
\hline Blue chalk & 0.832 & 24.7 & 5.2 & Lake \\
\hline Chub & 1.52 & 18.4 & 8.5 & Lake \\
\hline Crosson & 3.26 & 16.1 & 9.4 & Lake \\
\hline Dickie & 2.6 & 55.7 & 10 & Lake \\
\hline Harp & 3.04 & 44.6 & 7.1 & Lake \\
\hline Plastic & 0.669 & 14.8 & 5.7 & Lake \\
\hline Red chalk & 3.3 & 13.2 & 5.0 & Lake \\
\hline Mendota & 77.5 & 443 & 120 & SW \\
\hline Peipsi & 9,700 & 76 & 41 & SW \\
\hline Mjøsa & 9,300 & 26 & 9.4 & SW \\
\hline Mirror & 0.663 & 33 & 5.4 & Lake \\
\hline Vättern & 1,260 & 15 & 4 & Lake \\
\hline S Bergundasjön & 11.5 & 1,500 & 1,100 & SW \\
\hline Wahnbachtalsperre & 38.6 & 25.1 & 10 & Lake \\
\hline Fuschlsee & 38 & 29 & 15 & SW \\
\hline Bryrup Langsø & 6.3 & 210 & 110 & SW \\
\hline Salten Langsø & 93 & 120 & 52 & SW \\
\hline Walensee & 1,770 & 56 & 17 & SW \\
\hline Maggiore & 9,400 & 59 & 23 & SW \\
\hline Biwa & 5,000 & 106 & 36 & SW \\
\hline Gjersjøen & 21 & 80 & 20 & Lake \\
\hline Võrtsjärv & 830 & 84 & 48 & SW \\
\hline Tegernsee & 240 & 25 & 17 & SW \\
\hline Schliersee & 28 & 42 & 26 & SW \\
\hline Stugsjön & * & 14 & 7.0 & SW \\
\hline Magnusjaure & * & 9.5 & 4.0 & SW \\
\hline Lough Neagh & 2,837 & 169 & 109 & SW \\
\hline Geneva & 8,010 & 140 & 77 & SW \\
\hline Östra Ringsjön & 133 & 179 & 165 & SW \\
\hline Västra Ringsjön & 145 & 176 & 81 & SW \\
\hline Kolbotnvannet & 1.24 & 91.5 & 24 & Lake \\
\hline Lugano & 1,770 & 101 & 63 & SW \\
\hline Apopka & 208 & 228 & 170 & SW \\
\hline Bullaren & * & 50 & 36 & Lake \\
\hline Långsjön & * & 13.8 & 8.9 & Lake \\
\hline Balaton & * & 200 & 63 & Lake \\
\hline Batorino & * & 120 & 64 & Lake \\
\hline Miastro & * & 73.5 & 41 & Lake \\
\hline Naroch & * & 50.5 & 14 & Lake \\
\hline Erken & $*$ & 39 & 28 & Lake \\
\hline Minimum & 0.011 & 9.5 & 4 & \\
\hline Maximum & 9,700 & 1,500 & 1,100 & \\
\hline Mean & 1,235 & 121 & 65 & \\
\hline
\end{tabular}

erlands, Western Europe). We applied LakeMab, the JPJS model and three of the best static models from the comparison in Table 5 (Ostrofsky 2, Vollenweider and Walker) to the loading, fluxes and concentrations data set in Janse and Aldenberg (1990) and compared estimates. There were no data available on ADA, so direct $Q$ measurements were used instead. Morphological data on Lake Loosdrecht were taken from Ooms-Wilms and others (1999). Time series data on $C_{\text {in }}$ from five other lakes; Loch Neagh and Lakes Geneva, Södra Bergundasjön, Östra Ringsjön, and Washington 
Table 4. References Related to the Given Lake Data (Table 2)

a Edmondson and Lehman (1981), Maki and others (1987) and Quay and others (1986)

b Molot and Dillon (1993, 1997) and Dillon and Molot (1996, 1997)

c Rusak and others (1999)

d Torrey and Lee (1976), Brock and others (1982), Brock (1985) and Lathrop and others (1998)

e Nõges (2001)

f Holtan (1978, 1979) and Kjellberg (2004)

g Likens (1985)

h Kvarnäs (2001); http://infol.ma.slu.se/db.html

j Bengtsson (1978)

k Bernhardt and others (1985) and Sas (1989)

l Haslauer and others (1984)

m Andersen (1974)

n Zimmermann and Suter-Weider (1976) and Sas (1989)

o Mosello and Ruggiu (1985) and Sas (1989)

p Kunimatsu and Kitamura (1981) and Toyoda and Shinozuka (2004)

q Faafeng and Nilssen (1981)

r Haberman and others (2004) and Nõges and others (1998)

s Hamm (1978)

t Jansson (1978) and Ahlgren and others (1979)

u Sas (1989)

v Sas (1989) and Anneville and others (2002)

y Ryding (1983)

z Haande and others (2005) and Oredalen pers. comm.

aa Barbieri and Simona (2001)

ab Bachmann and others (1999) and Coveney and others (2005)

ac Håkanson (1995), Håkanson and Boulion (2002) and Malmaeus and Rydin (2006)

ad Nordvarg (2001)
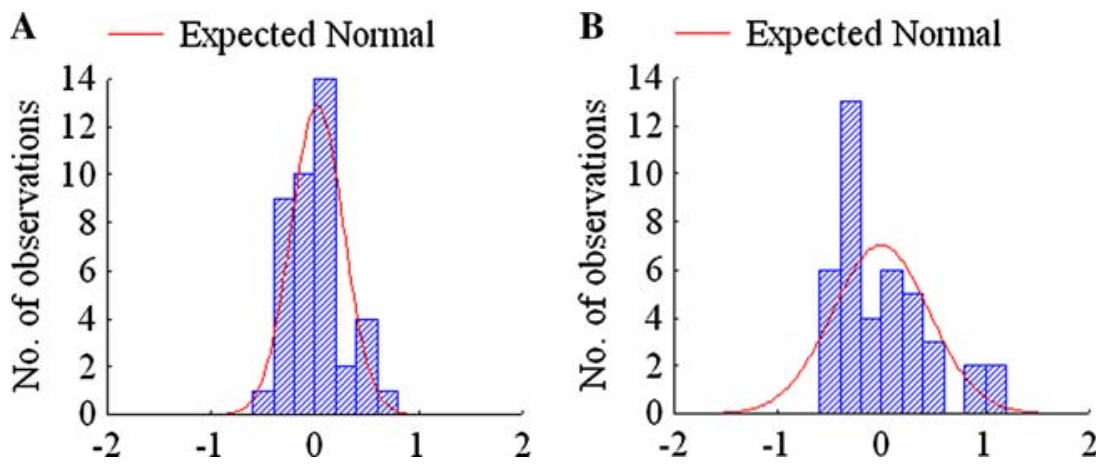

Figure 6. Frequency distribution of the relative error in modeled TP. A Errors from LakeMab. B Errors from Ostrofsky 2.

(for data sources, see Tables 2 and 4) were also used together with LakeMab, the JPJS model, and Ostrofsky 2, Vollenweider and Walker, to predict $C_{\text {lake }}$ in these lakes.

The dynamic models used here (LakeMab and the JPJS model) were both first calibrated with proper initial values for state variables, and using long-term values of $C_{\text {in }}$ as input data to reach a stable solution for all state variables, after which yearly $C_{\text {in }}$ data were used and predictions of $C_{\text {lake }}$ were compared to empirical values. An alternative strategy that was used in some cases was to utilize empirical data on $Q$, or assume that the loading to the lake was higher or lower than the first year from which $C_{\text {in }}$ data were available. The JPJS model could also be calibrated with different initial values for state variables to suit $C_{\text {lake }}$ values from the first year of each dataset, after which $C_{\text {lake }}$ was predicted for subsequent years. This strategy has previously been applied to the JPJS model (Jensen and others 2006), but it is not permitted for LakeMab (Håkanson and Boulion 2002).

Figures 7 and 8 show yearly mean predicted and actual $C_{\text {lake }}$ in the six lakes. The empirical uncertainty bands lie at $35 \%$ above and below empirical means, because $35 \%$ is the typical coefficient of 
Table 5. A Predictive Power and Error Comparison between LakeMab and 12 Static Models from Table 1, using Data for 41 Lakes

\begin{tabular}{|c|c|c|c|c|c|}
\hline Model & $\begin{array}{l}\text { Median relative } \\
\text { error }\end{array}$ & $\begin{array}{l}\text { Error correlated } \\
\text { with }\end{array}$ & $r^{2}$ mod-emp & $\begin{array}{l}\text { Median } \\
\text { Irelative errorl }\end{array}$ & $\begin{array}{l}\text { IErrorl } \\
\text { correlated with }\end{array}$ \\
\hline LakeMab & $0.02(0.25)$ & - & 0.96 & 0.17 & - \\
\hline K\&D & $-0.13(0.46)$ & Drel (+) & 0.78 & 0.40 & - \\
\hline LEM 1 & $0.09(0.58)$ & Area (-) & 0.81 & 0.31 & $Q(-)$ \\
\hline LEM 2 & $-0.16(0.53)$ & Drel (+) & 0.71 & 0.47 & - \\
\hline LEM 3 & $-0.03(0.49)$ & Drel $(+)$ & 0.80 & 0.38 & - \\
\hline Nürnberg & $-0.03(0.49)$ & Drel $(+)$ & 0.83 & 0.40 & - \\
\hline OECD & $-0.08(0.50)$ & Area $(-), C_{\text {lake }}(-)$ & 0.85 & 0.32 & $Q(-)$ \\
\hline Ostrofsky 1 & $-0.12(0.43)$ & $\operatorname{Drel}(+)$ & 0.84 & 0.39 & - \\
\hline Ostrofsky 2 & $-0.01(0.46)$ & $C_{\text {lake }}(-)$ & 0.86 & 0.35 & - \\
\hline Ostrofsky 3 & $-0.11(0.47)$ & Drel (+) & 0.77 & 0.43 & - \\
\hline Ostrofsky 4 & $-0.19(0.38)$ & Drel $(+)$ & 0.85 & 0.40 & - \\
\hline Vollenweider & $0.04(0.54)$ & Area (-) & 0.85 & 0.31 & $Q(-)$ \\
\hline Walker & $0.18(0.59)$ & Area (-) & 0.86 & 0.31 & $Q(-)$ \\
\hline
\end{tabular}

The relative error was calculated according to Eq. 2 and standard deviations are given in parentheses. $r^{2}$ mod-emp is the correlation coefficient between modeled and empirical data (log-transformed)

variation for TP in lakes and the uncertainty bands thus describe the probable outcome at the $70 \%$ confidence level (Håkanson and Peters 1995). Figure 7 compares empirical data to predictions from Ostrofsky 2, Vollenweider and Walker whereas Figure 8 compares empirical data with modeled data from LakeMab, the JPJS and PCLoos [the latter one only for Lake Loosdrecht; data from Janse and Aldenberg 1990)]. Table 6 shows the median deviation (in percent) between prediction and outcome for the six models and the six lakes.

According to Table 6 and Figure 8, the JPJS model performed very poorly without adjustment, although when initial values of state variables were decreased, predictions became much more certain, with the lowest overall error (9\%, Table 6). LakeMab also performed very well and was only adjusted for two lakes. When empirical $Q$ values were used and the pre-loading $C_{\text {in }}$ was assumed to be as high as in $1966\left(206 \mu \mathrm{g} \mathrm{L}^{-1}\right)$, the error in predictions for Lake Washington decreased considerably, from 38 to $18 \%$ (Table 6). However, predictions were even after this adjustment outside the uncertainty bands during the beginning of the period, and Lake Washington was the only lake whose transient $C_{\text {lake }}$ level was best predicted with statical models; particularly Ostrofsky 2 and Walker (Figure 7 and Table 6).

The second lake for which LakeMab was adjusted (the $C_{\text {in }}$ preceding the available time series was lowered to the 1983 value; $110 \mu \mathrm{g} \mathrm{L}^{-1}$ ) was Lake Geneva. Table 6 indicates that this adjustment of LakeMab actually gave poorer predictions, although Figure 8 shows that the first 6 years were slightly better described after the adjustment. $C_{\text {lake }}$ increased in Lake Geneva with about $80 \%$ after the first 6 years according to Sas (1989), although none of the models predicted such great change. This matter is further addressed in Figure 9, which shows that the Secchi depth [data from Sas (1989)] is fairly stable over time, although it should be anticipated to decrease sharply after 1960 in line with the increase in $C_{\text {lake }}$. Such stable conditions are very consistent with the $C_{\text {lake }}$ predictions from four of the models (Figures 7, 8), whereas the adjusted JPJS model predicted slightly altered conditions (Figure 8). The inconsistency between the significantly increased $C_{\text {lake }}$ and the stable Secchi depth in Figure 9 demonstrates that uncertain or erroneous measurements may very well be an important source of discrepancy between modeled and empirical data.

A consistent pattern regarding the remaining four lakes was that the adjusted JPJS model yielded the best predictions, followed by LakeMab. The three statical models generated larger errors than LakeMab and the worst predictions (except for Lake Östra Ringsjön) were delivered with the JPJS model without adjustments (Figures 7, 8 and Table 6). LakeMab predictions in Lake Loosdrecht were slightly better than those generated by PCLoos according to Table 6 and Figure 8. Those two dynamic models delivered rather similar predictions, which were the poorest in the beginning of the period. This cannot only be explained by uncertainty in empirical data, because the error in the annual mean value of 1982 was only about $25 \%$, judging from Figure $8 \mathrm{~B}$ in Janse and Alden- 

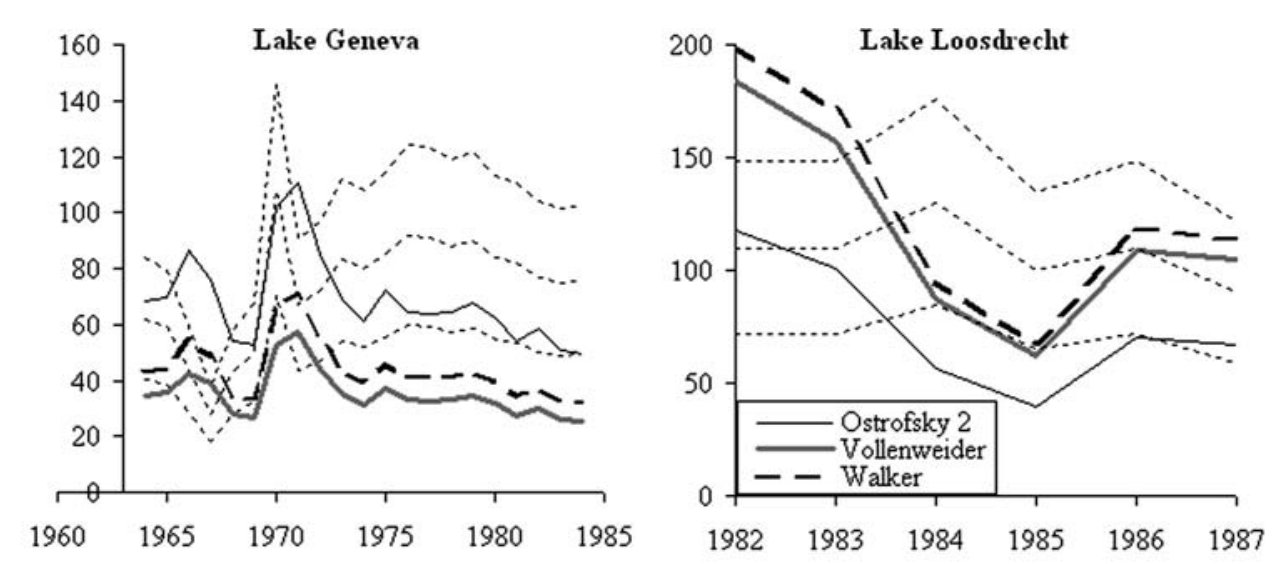

Figure 7. Static timeseries modeling. Simulated TP concentrations (in $\mu \mathrm{g} \mathrm{L}^{-1}$ ) in six lakes, with three static models. The three thin, dashed lines describe empirical data \pm 1 standard deviation.
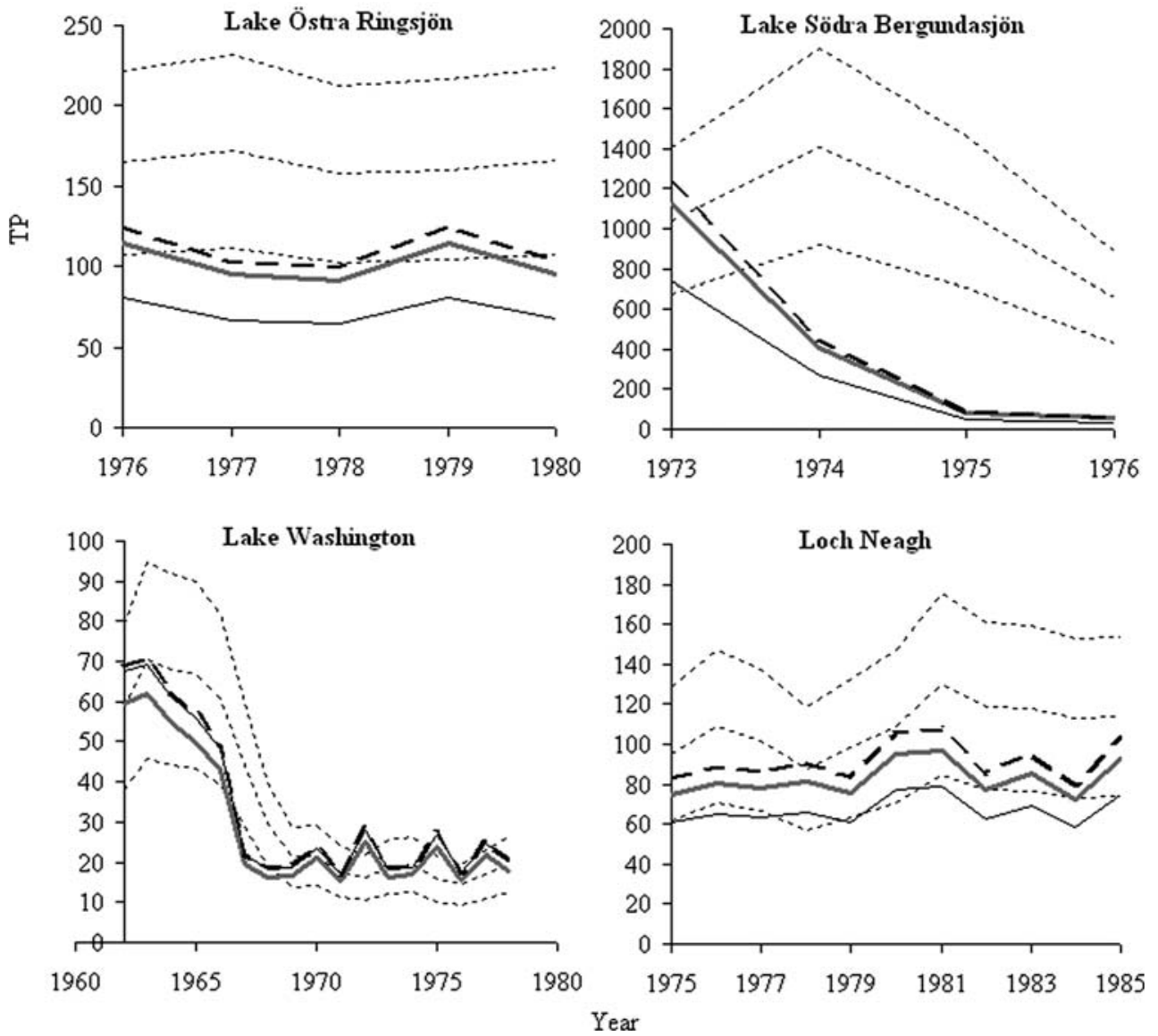

berg (1990). Nor can the error be explained by the absence of data from the preceding TP-loading history, because predictions over the whole period did not improve even if a lower or higher previous load was included in LakeMab simulations. Other possible error causes are model uncertainties, extreme weather conditions and systematic measurement errors. LakeMab generally seemed to predict $C_{\text {lake }}$ slightly better than PCLoos. However, the latter model predicted the average $R$ slightly better, at 0.54 compared to 0.58 from the massbalance (Janse and Aldenberg 1990), whereas
LakeMab predicted that $R$ was 0.53 . These slight differences may very well be insignificant. The three static models poorly described the internal loading and therefore tended to exaggerate the relationship between the $C_{\text {in }}$ and $C_{\text {lake, }}$ as well as the year-to-year variations in $C_{\text {lake }}$.

Although predictions from PCLoos and LakeMab were similar with respect to $R$ and $C_{\text {lake, }}$ predictions were much more different when fluxes were compared. The diffusion was usually about ten times as great according to LakeMab compared to PCLoos. Using PCLoos, Janse and Aldenberg (1990) 

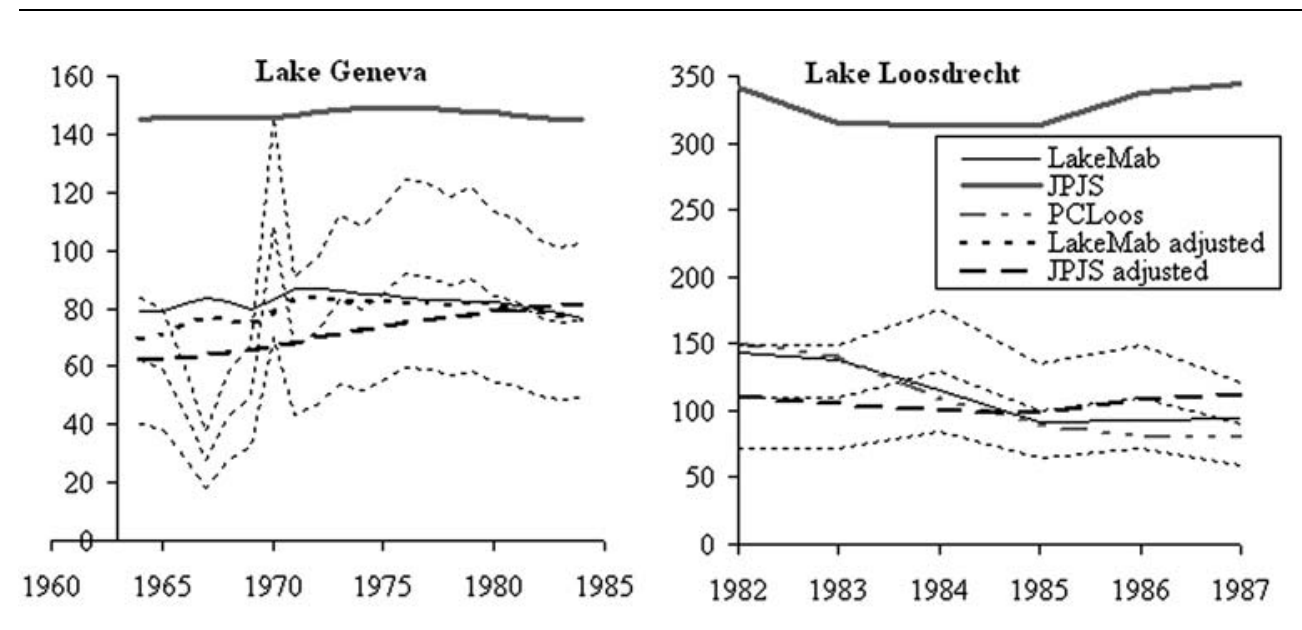

Figure 8. Dynamic timeseries modeling.

Simulated TP

concentrations (in $\mu \mathrm{g} \mathrm{L}^{-1}$ ) in six lakes, with three dynamic models. The three thin, dashed lines describe empirical data \pm 1 standard deviation.
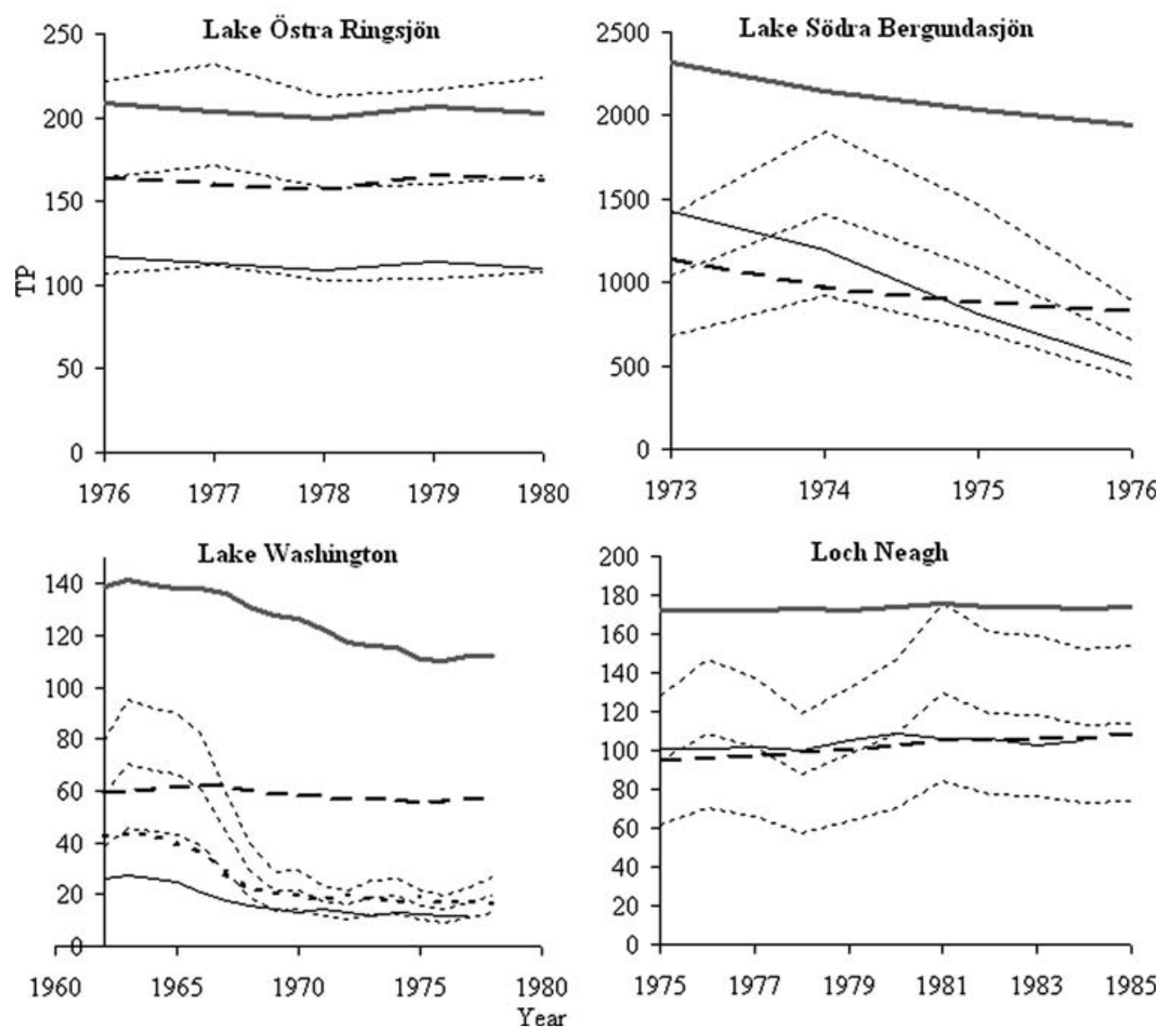

presented a simulated $P$ mass balance for the period April-September 1987, and Figure 10 shows some of the fluxes from that mass balance, compared to corresponding fluxes generated by LakeMab and the adjusted JPJS model. The P exchange through the sediment-water interface was slightly more intensive according to LakeMab than what PCLoos predicted. The main difference between those two models, however, is that LakeMab attributed 67\% of the upward flux from Lake Loosdrecht's sediments to diffusion and $33 \%$ of the flux to resus- pension, whereas PCLoos attributed much more $(82 \%)$ of the flux to resuspension. Which one of these flux attributions is the most correct one is an issue that remains to be solved, although in this context it is worth stressing that LakeMab has been developed, calibrated and tested for a much wider range of lakes than PCLoos and its successor PCLake, and its error function seems to be independent of lake type (Table 5).

Predictions from the adjusted JPJS model in Figure 10 were rather different than those from the 
Table 6. Median Percentual Difference between Prediction and Outcome for Time-Series Modeling of $C_{\text {lake }}$ in six Different Lakes and using Six Different Models

\begin{tabular}{lcclrcrcc}
\hline & PCLoos & LakeMab & $\begin{array}{l}\text { LakeMab, } \\
\text { adjusted }\end{array}$ & JPJS & $\begin{array}{l}\text { JPJS, } \\
\text { adjusted }\end{array}$ & Ostrofsky 2 & Vollenweider & Walker \\
\hline Geneva & & 9 & 11 & 89 & 13 & 25 & 58 & 51 \\
Loosdrecht & 20 & 13 & & 209 & 3 & 31 & 35 & 30 \\
Östra Ringsjön & & 31 & & 26 & 2 & 59 & 42 & 37 \\
Södra Bergundasjön & & 24 & & 104 & 23 & 88 & 81 & 80 \\
Washington & 38 & 18 & 487 & 174 & 15 & 20 & 14 \\
Loch Neagh & 8 & & 58 & 6 & 38 & 24 & 15 \\
Weighted median & & 18 & & 97 & 9 & 34 & 39 & 33 \\
& & & & & & & & \\
\hline
\end{tabular}

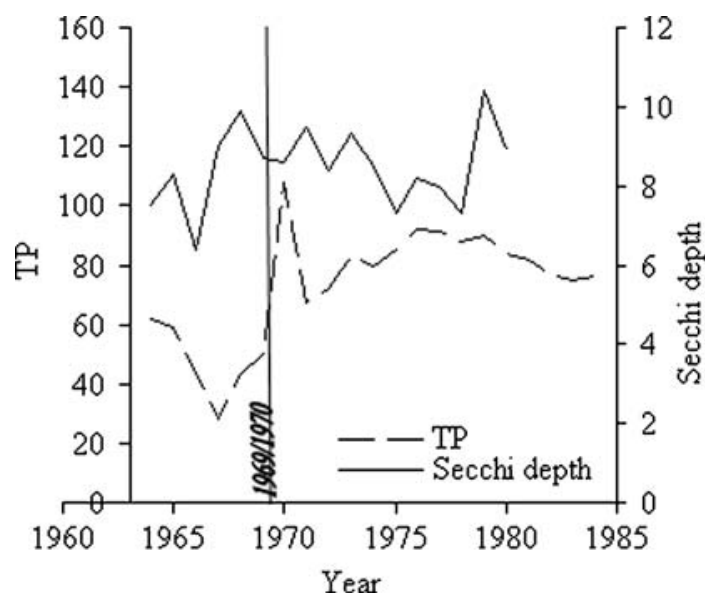

Figure 9. TP concentration $\left(\mu \mathrm{g} \mathrm{L}^{-1}\right)$ and Secchi depth (m) in Lake Geneva, 1964-1984. Data from Sas (1989).

other two models in the sense that sediment release was greater than sedimentation, which was the case for the whole simulation period, calculated on a yearly basis. This is a very unlikely scenario, given the fact that yearly $C_{\text {lake }}$ was always lower during the whole period than yearly $C_{\text {in }}$ (Janse and Aldenberg 1990). The explanation can be found in Figure 2, which shows that the JPJS model does not predict any long-term TP retention at all. In other words, $C_{\text {lake }}$ will approach $C_{\text {in }}$ over time. This is incorrect in a general sense. Macrophytes entrap $\mathrm{P}$ and prevent sediment resuspension even in shallow lakes and the burial process in such lakes is also well recognized (Søndergaard and others 2001) and is also the reason why shallow lakes are eventually filled with particulate matter and transformed into wetlands (Wetzel 2001). If a burial flux would be added to the JPJS model, predictions would probably be more reliable and some problems encountered by Jensen and others (2006) and in this work could perhaps be addressed. Such a model would also still be rather easy to operate for non-specialists with basic skills

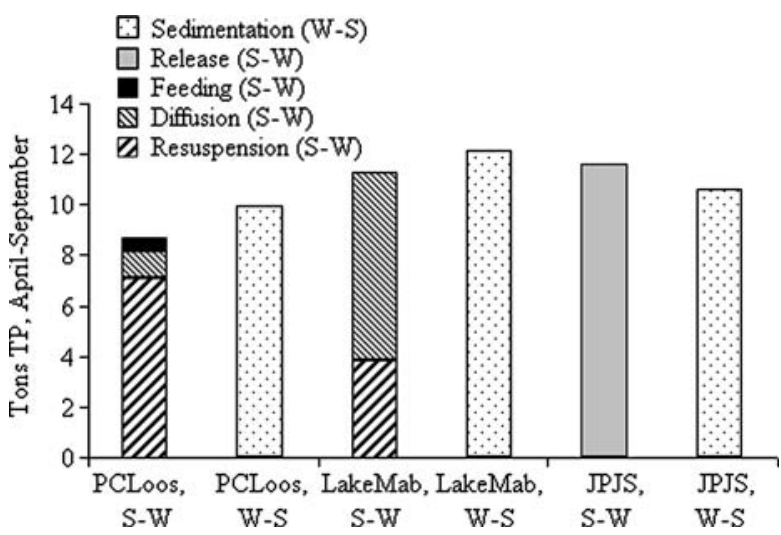

Figure 10. Comparison between fluxes simulated in Lake Loosdrecht, April-September 1987, with PCLoos, LakeMab and the JPJS model (adjusted). S-W is the flux from the sediment to the water, whereas the opposite flux is abbreviated W-S.

in programming and in solving ordinary differential equations. However, considering the way the JPJS model is constructed today (Figure 2), some of the outstanding predictions demonstrated in Table 6 are likely to be examples of "the right answers for the wrong reasons", as elaborated by Oreskes and others (1994).

\section{Concluding Remarks}

This work has evaluated and compared three general dynamic and 12 static TP load-concentration models for lakes. The main findings are: (1) The prediction error of the dynamic models was typically at $17-20 \%$, whereas the static models often yielded substantially poorer predictions, with errors of $30-50 \%$. One of the dynamic models (the JPJS model) was omitted from this comparison because it does not contain a burial flux. (2) To provide static models with input data, $Q$ and $C_{\text {in }}$ must be measured and a morphometric survey must be performed. Q can alternatively be modeled from 
Prec and ADA. LakeMab and the JPJS model have the same input requirements as static models, whereas PCLake additionally requires data on marsh area (if applicable), light, temperature and sediment characteristics. (3) Static models can predict $C_{\text {lake }}$ and $R$ in all types of lakes. LakeMab also predicts dissolved and particulate P, TP concentrations in sediments and in surface and bottom waters, as well as internal $P$ fluxes and burial in deep sediments. PCLake predicts $C_{\text {lake, }} R$, TP concentrations in sediments, several $P$ fractions, internal $P$ fluxes and burial, but only for shallow lakes. (4) One flaw with static models is that they do not describe internal $P$ fluxes, which LakeMab and PCLake (and their predecessors) do. Predictions of internal fluxes in Lake Loosdrecht differed considerably between two dynamic models. (5) Running general dynamic models still requires rather specialized knowledge, whereas static models are much easier to use. An important task for modellers should therefore be to design general dynamic models that can easily be used by other scientists, managers, policymakers and the general public.

Ideally, models should be as general as possible, apply to the widest possible range of lakes, quantify transport fluxes as realistically and mechanistically correct as possible, provide high predictive power and yet be driven by as readily accessible input variables as possible so that they can be applied to address key questions in lake management such as: How would " $\mathrm{my}$ " lake respond if the $\mathrm{P}$ inflow is reduced by $x \mathrm{~kg}$ in a given time period? Evidently, all models cannot be best according to these criteria and the best model cannot predict well in all lakes. But if a good model fails to predict well in a given lake, then the causal reason for the discrepancy may be found among factors not accounted for in the model and the reason for the discrepancy would then also be clarified more quickly and clearly. Understanding lake responses to remedial measures or stresses is a key item in lake management and a good model is, we believe, the best avenue to reach such understanding.

Generic dynamic TP load-concentration models have great potential to improve the assessment of the probable outcome from ambitious lake restoration programs, on local and regional scales, as well as on a global scale. This work is the first one to critically review and compare such models and the study has highlighted their advantages, disadvantages, possibilities and limitations. The findings in this work could inspire modelers to improve models, and serve as an important source of information to lake managers who wish to enhance their predictive understanding of the $\mathrm{P}$ cycle in lakes.

\section{ACKNOWLEDGMENTS}

We are greatly indebted to those cited scientists who have published detailed data on nutrient loads and concentrations. In addition, two anonymous reviewers provided many useful comments to earlier versions of this article.

\section{REFERENCES}

Abrahamsson O, Håkanson L. 1998. Modelling seasonal flow variability of European rivers. Ecol Modell 114:49-58.

Ahlgren I, Ramberg A, Jansson M, Lundgren A, Lindström K, Persson Petterson G K. 1979. Lake metabolism-studies and results at the Institute of Limnology in Uppsala. Arch Hydrobiol Beih Ergebn Limnol 13:10-30.

Ahlgren I, Frisk T, Kamp-Nielsen L. 1988. Empirical and theoretical models of phosphorus loading, retention and concentration vs. trophic state. Hydrobiologia 170:285-303.

Aldenberg T, Janse JH, Kramer PRG. 1995. Fitting the dynamic lake model PCLake to a multi-lake survey through Bayesian statistics. Ecol Model 78:83-99.

Andersen JM. 1974. Nitrogen and phosphorus budgets and the role of sediments in six shallow Danish lakes. Arch Hydrobiol 74:528-50.

Anneville O, Ginot V, Druart JC, Angeli N. 2002. Long-term study (1975-1998) of seasonal changes in the phytoplankton in Lake Geneva: a multi-table approach. J Plank Res 24:993-08.

Arhonditsis GB, Brett MT. 2005. Eutrophication model for Lake Washington (USA): part II-model calibration and system dynamics analysis. Ecol Modell 187:179-200.

Bachmann RW, Hoyer MV, Daniel E, Canfield DE. 1999. The restoration of Lake Apopka in relation to alternative stable states. Hydrobiologia 394:219-32.

Barbieri A, Simona M. 2001. Trophic evolution of Lake Lugano related to external load reduction: changes in phosphorus and nitrogen as well as oxygen balance and biological parameters lakes and reservoirs. Res Manage 6:37-47.

Bengtsson L. 1978. Effects of sewage diversion in Lake Södra Bergundasjön. 1. Nitrogen and phosphorus budgets. Vatten $1: 2-9$.

Bernhardt H, Clasen J, Hoyer O, Wilhelms A. 1985. Oligotrophication in lakes by means of chemical nutrient removal from the tributaries, its demonstration with the Wahnbach Reservoir. Arch Hydrobiol Suppl 70:481-533.

Brock TD. 1985. A eutrophic lake: Lake Mendota, Wisconsin. New York: Springer, p 308.

Brock TD, Lee DR, Janes D, Winek D. 1982. Groundwater seepage as a nutrient source to a drainage lake: Lake Mendota, Wisconsin. Water Res 16:1255-63.

Coveney MF, Lowe EF, Battoe LE, Marzolf ER, Conrow R. 2005. Response of a eutrophic, shallow subtropical lake to reduced nutrient loading. Freshw Biol 50:1718-30.

de Madariaga BM, M José Ramos MJ, Tarazona JV (2006) Development of a European quantitative eutrophication risk assessment of polyphosphates in detergents-model implementation and quantification of the eutrophication risk associated to the use of phosphate in detergents. Green Planet Research Report GPR-CEEP-06-2, p 126.

Dillon PJ, Rigler FH. 1974. The phosphorus-chlorophyll relationship in lakes. Limnol Oceanogr 19:767-73. 
Dillon PJ, Molot LA. 1996. Long-term phosphorus budgets and an examination of a steady-state mass balance model for central Ontario Lakes. Water Res 30:2273-80.

Dillon PJ, Molot LA. 1997. Dissolved organic and inorganic carbon mass balances in central Ontario lakes. Biogeochemistry 36:29-42.

Dodds WK. 2003. Misuse of inorganic N and soluble reactive $\mathrm{P}$ concentrations to indicate nutrient status of surface waters. J North Am Benthol Soc 22:171-81.

Edmondson WT, Lehman JT. 1981. The effect of changes in the nutrient income on the condition of Lake Washington. Limnol Oceanogr 26:1-29.

Faafeng B, Nilssen JP. 1981. A twenty-year study of eutrophication in a deep, soft-water lake. Verh int Verein Limnol 21:380-92.

Haande S, Oredalen TJ, Brettum P, Løvik JE, Mortensen T (2005) Monitoring of Lakes Gjersjøen and Kolbotnvannet with tributaries 1972-2004 with focus on results from the 2004 season. Niva report 5010-2005. Niva, Oslo, p 109 (in Norwegian).

Haberman J, Pihu E, Raukas A. 2004. Võrtsjärv. Tallinn: Estonian Encyclopedia, p 542.

Håkanson L. 1995. Aquaculture and environmental effects in lakes-new results motivate new bases of assessment. Lund: Bloms, p 105 (in Swedish).

Håkanson L. 2000. Modelling radiocesium in lakes and coastal areas-new approaches for ecosystem modellers. A textbook with Internet support. Dordrecht: Kluwer, p 215.

Håkanson L. 2006. Suspended particulate matter in lakes, rivers and marine systems. New Jersey: Blackburn, p 319.

Håkanson L, Jansson M. 1983. Principles of lake sedimentology. Berlin: Springer, p 316.

Håkanson L, Peters RH. 1995. Predictive limnology-methods for predictive modelling. Amsterdam: SPC Academic Publishing, p 464.

Håkanson L, Boulion V. 2002. The lake foodweb. Leiden: Backhuys, p 344.

Hamm A. 1978. Nutrient load and nutrient balance of some subalpine lakes after sewage diversion. Verh Internat Verein Limnol 20:975-984.

Haslauer J, Moog O, Pum M. 1984. The effect of sewage removal on lake water quality (Fuschlsee, Salzburg, Austria). Arch Hydrobiol 101:113-34.

Hasler AD. 1947. Eutrophication of lakes by domestic drainage. Ecology 28:383-95.

Holtan H. 1978. Eutrophication of Lake Mjøsa in relation to the pollutional load. Verh Int Ver Limnol 20:734-42.

Holtan H. 1979. The Lake Mjøsa story. Arc Hydrobiol Beih 13:242-58.

Jackson LJ, Jackson AS, Trebitz, Cottingham KL. 2000. An introduction to the practice of ecological modelling. Bioscience 50:694-06.

Janse JH 2005 Model studies on the eutrophication of shallow lakes and ditches. PhD thesis, Wageningen University, p 378.

Janse JH, Aldenberg T. 1990. Modelling phosphorus fluxes in the hypertrophic Loosdrecht Lakes. Aquatic Ecol 24:69-89.

Jansson M. 1978. Experimental lake fertilization in the Kuokkel area, northern Sweden: budget calculations and the fate of nutrients. Verh Internat Verein Limnol 20:857-62.

Jensen JP, Pedersen AR, Jeppesen E, Søndergaard M. 2006. An empirical model describing the seasonal dynamics of phos- phorus in 16 shallow eutrophic lakes after external loading reduction. Limnol Oceanogr 51:791-800.

Jeppesen E, Søndergaard M, Jensen JP, and others.2005. Lake responses to reduced nutrient loading-an analysis of contemporary long-term data from 35 case studies. Freshw Biol 50:1747-71.

Kirchner WB, Dillon PJ. 1975. An empirical method of estimating the retention of phosphorus in lakes. Water Resour Res 11:182-83.

Kjellberg G (2004) Management oriented monitoring of Lake Mjøsa with tributaries. Annual data report for 2003. NIVA report 4319-2004. NIVA, Oslo, p 91 (in Norwegian).

Kunimatsu T, Kitamura G. 1981. Phosphorus balance of Lake Biwa. Verh Internat Verein Limnol 21:539-544.

Kvarnäs H. 2001. Morphometry and hydrology of the four large lakes of Sweden. Ambio 30:467-74.

Larsen DP, Mercier HT. 1976. Phosphorus retention capacity of lakes. J Fish Res Board Can 33:1742-50.

Lathrop RC, Carpenter SR, Stow CA, Soranno PA, Panuska JC. 1998. Phosphorus loading reductions needed to control bluegreen algal blooms in Lake Mendota. Can J Fish Aquat Sci 55:1169-78.

Likens GE (Ed.) (1985) An ecosystem approach to aquatic ecology: Mirror Lake and its environment. New York: Springer. p 516.

Maki JS, Tebo BM, Palmer FE, Nealson KH, Staley JT. 1987. The abundance and biological activity of manganese-oxidizing bacteria and metallogenium-like morphotypes in Lake Washington, USA. FEMS Microbiol Ecol 45:21-9.

Malmaeus JM, Håkanson L. 2004. Development of a lake eutrophication model. Ecol Modell 171:35-63.

Malmaeus JM, Rydin E. 2006. A time-dynamic phosphorus model for the profundal sediments of Lake Erken, Sweden. Aquatic Sci 68:1015-1621.

Meeuwig JJ, Peters RH. 1996. Circumventing phosphorus in lake management: a comparison of chlorophyll a predictions from land-use and phosphorus-loading models. Can J Fish Aquat Sci 53:1692-94.

Molot LA, Dillon PJ. 1993. Nitrogen mass balances and denitrification rates in central Ontario lakes. Biogeochemistry 20:195-12.

Molot LA, Dillon PJ. 1997. Colour-mass balances and colourdissolved organic carbon relationships in lakes and streams in central Ontario. Can J Fish Aquat Sci 54:2789-95.

Mosello R, Ruggiu D. 1985. Nutrient load, trophic condition and restoration prospects of Lake Maggiore. Int Rev Ges Hydrobiol 70:63-75.

Nõges T, Ed. 2001. Lake Peipsi: hydrology, meteorology, hydrochemistry. Tartu: Sulemees, p 163.

Nõges P, Järvet A, Tuvikene L, Nõges T. 1998. The budgets of nitrogen and phosphorus in shallow eutrophic Lake Võrtsjärv (Estonia). Hydrobiologia 363:219-27.

Nordvarg L. 2001. Predictive models and eutrophication effects of fish farms. DissertationThesis, Uppsala University, Sweden.

Nürnberg GK. 1984. The prediction of internal phosphorus load in lakes with anoxic hypolimnia. Limnol Oceanogr 29:11124.

Ooms-Wilms AL, Postema G, Gulati RD. 1999. Population dynamics of planktonic rotifers in Lake Loosdrecht, the Netherlands, in relation to their potential food and predators. Freshw Biol 42:77-97. 
Oreskes N, Shrader-Frechette K, Belitz K. 1994. Verification, validation, and confirmation of numerical models in the earth sciences. Science 263:641-46.

Ostrofsky ML. 1978. Modification of phosphorus retention models for use with lakes with low areal water loading. J Fish Res Board Can 35:1532-36.

Peters RH. 1986. The role of prediction in limnology. Limnol Oceanogr 31:1143-59.

Peters RH. 1991. A critique for ecology. Cambridge: Cambridge University Press, p 366.

Pienitz R, Smol JP, Lean DRS. 1997. Physical and chemical limnology of 59 lakes located between the southern Yukon and the Tuktoyaktuk Peninsula, northwest territories (Canada). Can J Fish Aquat Sci 54(2):330-46.

Popper K. 1972. Conjectures and refutations: the growth of scientific knowledge. 4th edn ed. London, Henley: Routledge and Kegan Paul, p 431.

Prairie Y. 1996. Evaluating the predictive power of regression models. Can J Fish Aquat Sci 53:490-92.

Quay PD, Emerson SR, Quay BM, Devol AH. 1986. The carbon cycle for LakeWashington-a stable isotope study. Limnol Oceanogr 31:596-611.

Reckhow KH. 1988. Empirical models for trophic state in southeastern U.S. lakes and reservoirs. Water Resour Bull 24:723-34

Rusak JA, Yan ND, Somers KM, McQueen DJ. 1999. The temporal coherence of zooplankton population abundance in neighboring north-temperate lakes. Am Nat 153:46-58.

Ryding S-O. 1983. The Lake Ringsjön area-changing ecosystems. Uppsala: Uppsala University, Department of Limnology.

Sas H, Eds. 1989. Lake restoration by reduction of nutrient loading: expectations, experiences, extrapolations. St. Augustin: Academia Verlag Richarz, p 497.
Schindler DW. 1977. Evolution of phosphorus limitation in lakes. Science 195:260-62.

Schladow SG, Hamilton DP. 1997. Prediction of water quality in lakes and reservoirs: part II-model calibration, sensitivity analysis and application. Ecol Modell 96:111-23.

Søndergaard M, Jensen JP, Jeppesen E. 2001. Retention and internal loading of phosphorus in shallow, eutrophic lakes. Scientific World 1:427-42.

Torrey MS, Lee GF. 1976. Nitrogen fixation in Lake Mendota, Madison, Wisconsin. Limnol Oceanogr 21:365-78.

Toyoda K, Shinozuka Y (2004) Validation of arsenic as a proxy for lake-level change during the past 40,000 years in Lake Biwa, Japan. Quaternary International 123-125:51-61.

Vleeshouwers LM, Janse JH, Aldenberg T, Knoop JM. 2004. A metamodel for PCLake. RIVM report 703715007. Bilthoven: National Institute for Public Health and the Environment, $p$ 24.

Vollenweider RA (1968) The scientific basis of lake eutrophication, with particular reference to phosphorus and nitrogen as eutrophication factors. Tech. Rep. DAS/DSI/68.27, Paris: OECD, p 159.

Vollenweider RA. 1976. Advances in defining critical loading levels for phosphorus in lake eutrophication. Mem Ist Ital Idrobiol 33:53-83.

Wetzel RG. 2001. Limnology. London: Academic, p 1006.

Zhang JJ, Jørgensen SE, Mahler H. 2004. Examination of structurally dynamic eutrophication model. Ecol Modell 173:313-33.

Zimmermann U, Suter-Weider P. 1976. Contributions to the limnology of lakes Walensee, Zürich-Obersee and Zürichsee. Schweiz Z Hydrol 38:71-96 (in German). 